\title{
Cross- Culture Dialogue in R.K. Narayan's My Dateless Diary
}

\author{
Pulkita Anand \\ Assistant Professor, Department of English and Modern European Languages, Banasthali \\ Vidyapith, Rajasthan. ORCID: oooo-ooo3-0586-3975. Email:pulkitaanand@ymail.com
}

\begin{abstract}
Man has desires to explore the unexplored, to chart the uncharted, and to know the unknown. R K Narayan takes us to different terrain in his work My Dateless Diary: An American Journey (1960). Though the book was written quite late by Narayan, it has an unmistakable stamp of his style and ease. Written in the firstperson, it takes us directly to the core of the writer's persona and his idiosyncrasies. The book is about a journey to America and self in the act of writing, journeying inside and outside the world. It is a conglomeration of fact and fiction, memories and desires, experience and observation, self and other, and the East and the West. The word 'dateless' is metaphoric in a way that many things are still prevalent in the present time. In his witty and amusing tone, Narayan draws up the subtle difference in linguistic, cultural, social, economical, religious and professional aspects of American and Indian ways of life, which at once invites comparison and contrast. It seems to be a mingling of two cultures in literature. Narayan reveals how we Indians get easily adjusted and assimilated in any culture. He also depicts no desire on the parts of Indians to subvert this general representation. The paper aims to dwell on these aspects as reflected in the text. It also attempts to see how Narayan juxtaposed the Indian and American ways of life, and how they complement each other in their ways.
\end{abstract}

Keywords: India, America, culture, life, travel, self.

\section{Introduction}

Each one of us has travelled for some reason or the other, from our home, from our country, from one country to another. Despite the death of many genres and forms, travel is still alive and will remain an enchanting experience for the traveller across the globe. People have been travelling across the globe out of curiosity too. Sigmund Freud postulated that "a great part of the pleasure of travel lies in the fulfillment of these early wishes..... to escape the family." (quoted in Weinstein, 2001, p.79). In this sense, the act of travelling is an act of rebellion, subverting the authority, a challenge to the state of affairs, and dismantling the status quo. According to Barbara Korte "the travelogue is a genre not easily demarcated" (2000, p.1). She further adds, "As far as its theme and content matter are concerned, the travel account has not emerged as a genre hermetically sealed off from other kinds of writing" (200o, p.8). William Spengemann and Charles Batten have explicated that the equation between fact and travel writing is complex; the difference between fact and fiction in this most eclectic of genres would be difficult to fix it (Spengemann, 1977; Batten, 1978). Paul Fussell in his work Abroad: British Literary Travelling between the Wars further adds that if a person doesn't travel there would be, "a loss of amplitude, a decay of imagination and intellectual possibility corresponding to the literal loss of physical freedom." (1982, p. 10)

\footnotetext{
(C) AesthetixMS 2020. This Open Access article is published under a Creative Commons Attribution Non-Commercial 4.o International License (http://creativecommons.org/licenses/by-nc/4.o/), which permits non-commercial re-use, distribution, and reproduction in any medium, provided the original work is properly cited. For citation use the DOI. For commercial re-use, please contact editor@rupkatha.com.
} 


\section{R.K. Narayan as a travel writer}

R. K. Narayan (1906-2001), the famous Indian writer in English, won the coveted Sahitya Akademi award in 1958 and other eminent awards for his contribution to literature. He is also remembered for creating Malgudi in the life and heart of Indians. His renowned works are Swami and Friends, The Bachelor of Arts, The English Teacher, Mr. Sampath, The Financial Expert, The Man-eater of Malgudi and many more. Apart from novels, he wrote non-fiction, short stories, essays, articles, and travelogue. My Dateless Diary: An American Journey is his autobiographical travelogue which transcends boundaries. In 1956, at the age of fifty, Narayan left India for the first time and journeyed to America on a Rockefeller Fellowship. My Dateless Diary is the output of a daily journal he maintained during this visit where he gives detached and impersonal comments on the things he observed and the people he encountered. In this account of his journey, he captures the clamour and energy of New York City, the friendliness of the West Coast, the wealth and insularity of the Mid-West, the magnificence of the Grand Canyon. Threading their way through the narrative are a host of delightful characters-from celebrities like Greta Garbo, Aldous Huxley, Martha Graham, Cartier Bresson, Milton Singer, Edward G. Robinson and Ravi Shankar to the anonymous business tycoon on the train who dismissed the writer when he discovered Narayan had nothing to do with India's steel industry. To add to this, there are interesting vignettes of those small but essential aspects of American life-muggers, fast food restaurants, instant gurus, subway commuters, TV advertisements, and American football.

In this work there is an indelible stamp of Narayan's style which includes his art of storytelling, humour, gentle sarcasm and lucidity, graphic details, swiftness, racy and vigorous manner. There are snippets and titbits of historical accounts too that rouses the imagination of the reader. It is marked with enlivening observation, picturesque description, brevity and liveliness. We also come to know about the different facets of his life. A. Phaniraja Kumar rightly states, "It is the study of the cultural differences which Narayan observed, experienced and recorded." (2013, p. 363) We come across different views of Narayan which at times seems Indian and at times American.

Narayan's travelogue demonstrates his awareness of the genre and his devotion to the craft of fiction. He warded off the banality of travel writing through his keen observation and charming humour by using the same craft that he has used in his fiction writing. He has employed drama, suspense, simile, metaphor, and personification. Narayan is the character and narrator in this work. His nature will unfold in the process of self-discovery that writing can provide. Thus narration of travel writing is a conduit that provides Narayan a medium through which he turned out to be an absorbing storyteller. He at times avoids describing mundane and banal things. He paces up his telling to sustain suspense and interest. Every incident that Narayan describes has a grain of drama and fiction in it. Travel is a quest which at times seems spiritual with respect to Narayan. He is a mystic from India who enquired after the meaning and purpose of life. On his journey, he meets many tormented souls undergoing trial and tribulation. The unique nature of this travel narrative is revealed by the author himself in the Foreword to the Penguin edition of the book which he wrote as late as 1988:

Datelessness has its limit. Sooner or later the seal of date shows up even in the most indifferently maintained diary.

I don't know how to classify this book. It is not a book of information on America, nor is it a study of American culture. It is mainly autobiographical, fill of 'I' over a short period of time in relation to some moments, scenes and personalities. 
The book was written thirty years ago and I do not know, as I've said at the beginning of this foreword, how far 'dateless-ness' can hold. (Narayan, Foreword, 1988; n.p.)

But it seems the work is dateless in its own way, as it is fresh, vibrant, inspiring, guiding, and enlightening. Written in the first person, it takes us on a journey with Narayan who discovers America, a nation peopled by beautiful humane and amusing, men and women. The text is divided into various sections indicating the places and people that he visited and met in the course of his journey. We feel we too have been travelling to these places and meeting these people. Narayan, a writer true to his vocation, takes his readers to the place where he wants them to, we transcend the limits of time and space, and the journey seems to be 'dateless.'

\section{Analysis of My Dateless Diary: An American Journey}

From the very beginning of the narrative, the cultural variation between India and America is depicted subtly and slyly when Narayan goes to a Broadway cafeteria. In our country, we are used waiting for a waiter to take our orders. Narayan states how at a cafeteria he mistakes, "waiting for someone to ask what I wanted." (Narayan, 1969, p. 7) He learned that he has to "pull out a 'check'..." pick up his tray and spoons and adjudge the content of the dish, if he does it longer they might ask, "What do you want?" (p.7). While in India, you just take a seat, ask for the newspaper, you may order or delay it further by asking, "What have you?" (p.7). It's amusing when he was asked about his liking for coffee, "Black or White? (p.8)" to which he replied brown. That must have sounded like a crazy thing to an American ear. It is a reflection of how we, and how they look at things. When someone heard him saying this, approached him, and inquired about the coffee, which Narayan described in detail. He felt as if he had a "God-given opportunity for me to start off a lecture on coffee, its place in South India...its place in our social life...(p.9). He explicated that how making a good coffee is a matter of pride, reputation and family prestige in India. It requires deliberate efforts at every stage, from "feeling for quality" to "eye for colour," from "adding sugar" to "without producing sweetness," from the selection of seeds to roasting, from grinding to straining (p.9). Narayan was astonished to see aged people doing daring things and felt, "With so many facilities in civilization one simply could not afford to grow old" (p.11) and further he heard, "Age has no chance in New York". He saw how women try to hide their age through various means. He found some in "the skirts and jackets had a resemblance to the dhoti that South Indians wear." (p.12) He was much surprised to see "the abandoned fashion of India adopted by the women of New York as the latest." (p.12) In India, women put castor leaf on their heads to protect from the sun, but their women put it as a fashion.

Narayan takes us to various places in New York such as the Statue of Liberty, the Empire State Building, and Rockefeller Plaza. When he chanced to see a shop selling Indian stuff, he had a peek into it, a passerby asked him, whereon upon he felt proud to describe ivory of Mysore. In his witty manner, he talks about the reasons why people give the address of their known, "mercenary ...to carry pickles and spices from India, to know them..." (p.15). He was baffled at the linguistic variations when asked at the subway counter, "Up-town or down-town?"(p.15). Humour is interspersed in his writing everywhere. When he said, "Vegetarian" people around were shocked as if he had said, "Man-eater". They wonder how he is alive on this diet. People around him got inquisitive about Gandhi and asked many things about the Mahatma. They were "proud to have seen a man from 'Gandhian land." (p.17)

Narayan was overwhelmed by publishers' responses to his work. He was impressed by their enthusiasm, warmth and genial nature. But at the same time, he failed to decide among 
them. Once on his walk, he met a dog lover with his two dogs. On getting into the conversation with him, the man asked, "Is it a fact that you have a population -over 400 million, Oh God, what a number, and most of them die of starvation?" (p. 23) He came to know that a lady whom he met at J's home at dinner was interested to meet him. She read his work, Grateful to Life and Death (The English Teacher). She was fascinated by the ending and had some queries about afterlife communication to which Narayan didn't know what to say.

He was impressed by the response of the lady, Miss Roser, at National Broadcasting Corporation, Broadway. "She was interested in India and had a fantastically remote, unguessable link with it." (p.31) There was Halloween celebration when he visited Mrs. X, during this time pumpkin seeds were roasted. He observes an interesting fact about Americans, they "like to know how far they are being liked by others." (p.36) He realizes that within the country itself there were small prides and prejudices which one must fully appreciate if one is to understand the country and its people. Apart from that, Narayan finds other differences within this country, "To a Southerner the rest of the United States is an immature undeveloped country... the New Englander is proud of his heritage of sober English qualities...the West Coast is an extremely proud country, their wealth."(p.37) On being asked by Mrs. Dorothy, what marks an average American from an Indian, he replies, “...American is totally materialistic in the best sense of term, work, wages, good wife, and good life, while an Indian will be bothering about the next life also in addition to all this." (p. 38) Narayan longs for Indian food. When he gets an opportunity to have an exquisite dinner with ex- Maharaja at the Indian Consulate, he savours, "South Indian foodRasam, Sambhar, Masala Dosai, pickle and so forth." (p. 40) He describes how he is understood and misunderstood by the people there.

Narayan saw that the American people were not excited on election day, whereas in India it was " full of noise, crowd and movement, with all normal work suspended; and above all loudspeakers rending the air." (p.46) In a discussion on his book, The Financial Expert which he wrote earlier, he didn't recall it fully and dreaded on being asked questions on it. In reply to one of the questions, he talked about joint family in India; towards the end of the lecture an elderly person came to him and showed his photograph that they too lived in a joint family. Indian Society, its origin, joint family, are the fascinating topics of discussion in America. Americans are amused by the exotic lifestyle.

At East Lansing, he then describes how Indian youth succumb to the lifestyle of America and adopt the American way of living by citing the story of Govind. In his tongue in cheek manner, he expresses how he was flabbergasted when asked about his book, The English Teacher, as odd or eccentric. Rattner, an artist asked him about the solution for American civilization, he added, "We have everything in the world, yet are unhappy. We as a nation are terribly bored; and so seek continuous forgetfulness in excitement, gadgets and so forth." (p. 54) Suicide and divorce cases are also increasing. The questions about how should human beings live, boggle people since the time of Aristotle. To this Narayan gives a solution, which lies in prayer and meditation, looking at the Indian side, "it may be one of the reasons why, with all our poverty and struggle, we still survive, and are able to take a calm view of existence." (p.54) It was a dreadful experience for him when he travelled in a train from Chicago to Madison, as football was in the air. The train was full of football players, he felt himself, "a heretic in this land of football worshippers." (p.56) His visit to Henry and Virginia in Adam Street consists of moments of joy and sorrow, as Benny, their child disappeared for some time. His writing is interspersed with some advice as: "an author should never give a reading of his or her own masterpiece, nor should he try to explain it. It always produces an effect of bathos." (p. 62) 
An interesting thing about the English language is its accent. J. C. Wells aptly states, "There are Indians educated at British public schools whose accent is unquestionably RP. There are Indians with a fair knowledge of English whose accent is ....impenetrable that English people can understand them, if at all, only with the greatest difficulty." (1982, p. 624) During his visit to the University Union, Narayan met a lady Mrs R, who started making fun of him when he said, "Gil suddenly developed pneumonia" and she corrected his accent to which Narayan felt, "So much of accent seems to me a waste of breath; we've always been taught to speak without accent." (p. 63) She repeated jokes on 'developed pneumonia' which resulted in her catching pneumonia. As people are affluent in America most of them have cars, which result in the problem of parking. It is available at ten minutes' time. So, one has to watch the watch to get the parking space.

Narayan displays how awkward it becomes for him and others when he met people from the English Department. They were wondering, how he would take, as they didn't read his books, what to ask about his books, what questions to be put forth. His presence seems to them like, “...having a living author on hand may be like having a live lobster on your plate (p.66)". In his lively, playful tone Narayan presents the psyche of the human beings. We get into the banal, vapid and inane conversation for the sake of communication. He also makes a splendid comparison of Indian and American architecture when he visited with Henry's friend to see Frank Lloyd Wright's design and Sullivan's. "American cherish antiquities -in many of the homes, the most cherished object is a piece of mat or a brass vase or a verdigris- covered image from India, while in an Indian home the proudest possession would be a chromium-finished cigarette-lighter or a cuckoo-clock from Switzerland."(p.67) He is at his loss when he was travelling in the train, as the train has 'Coach Class' and 'Parlour Class' in it.

In Chicago, he spent time with Redfield, a singer, and Shils, an eminent professor. There, he also met Dr. M. N. Srinivas, an eminent sociologist. Dr. Srinivas read his manuscript of Swami and Friends and mentioned that it is readable. He desired to meet him, not only because he would speak Tamil with him but also get betel-nut of which he was addicted to. He attends a class at the suggestion of Milton Singer, and the lecture was on Joint Family, which was a rage in academic circles in that country. They wondered how many people live, work and budget things under one roof, to which Narayan highlighted the benefits, "...an extreme sense of security in the children...disciplined by uncles or others...the old parents never lose touch with the affairs of the family." (pp.72-3) Evening at Milton Singer's house was Madras-in-Chicago; he enjoyed Madras' food, titbits from Madras, discussion on Madras culture, religion, architect, and music. Singer's interest made him to comment, "He must have been a Tamilian in a previous birth." (p.77). On Thanksgiving Day, he enjoyed the hospitality and cordial dinner at Shil though, on the same day, when he was charged high from the barber on the pretext of Thanksgiving, he observes that on Thanksgiving, "No shop, no bank, nothing doing ... 'Legal' holiday." (p.78)

During his stay at Berkeley, Narayan hunted for a house and thought of leaving his hotel room, as staying in an apartment would be economical. But his hunt turned futile, he could not come to a conclusion and shuttled from hotel to apartment and back to the hotel. He visited various places in San Francisco along with John, and with him also went to Oakland to see the haunts of Jack London. He had a frightening experience at San Francisco Key Station, when two strangers snapped his ticket, and then threatened him, and persuade him to buy a watch. Narayan has shared his strange behaviour initially in his writing that he never kept a watch, as he didn't rely on this instrument. On being forced by these strangers, he with his sound argument convinced them and left them dumfounded. 
On his way to Albany, he was amused by the name of the places such as, "Euclid, Scenic, Cedar, Spruce, Sonoma, Pomona, Carmel." (p.98) There, the Indian community celebrated Diwali with the same fanfare as we did in India. Fixico states, "Indian people learn to adjust, altering their family structure and personality, and simultaneously threatening their distinct culture, forcing them to deal with society's problems such as racial differences in an urban setting." (200o, p. 176).

Once he was interviewed by Bob, a young man. Though Narayan was amused whenever asked, "Are your books available in English translation?" (p.109) he was impressed by the versatility, warmth and affection shown by this young man. He finds their love for "yeah" words. This he has also used in one of his essays entitled, "Toasted English." He was baffled and felt dejected when he saw mortician's advertisements. It seems in this country everything is for sale. At the post-office, a lady inquired about Gandhi, revolution, and found an affinity between India and America, as both were ruled by the Britishers.

Americans pronounce Buddha as Bew-da or Booda. He finds that they make fun of God. They are impressed by Buddhism. They claim to be a follower of Buddhism, when asked what you do, they simply reply, "Nothing. You are just a Buddhist-that's all." (p.118) He observes, "Irreverence, Blasphemy, are here as compelling a creed as any religious practice in a monastery." (p.119) Discussing with his friends how old people have been taken care of in America, he came to know about the old age homes and also about the estranged parents-children relationship. He came to know another fact of American life, children are considered, "an unmanageable nuisance in this country." (p.122) The Americans in turn, are interested to know about the difference between Hindu and Muslim, and the reason for the flight between them in India.

On a sudden encounter with an old man, who inquired about his daughter, to the joy of both Narayan and the old man, he knew who the old man was talking about. To which the old man comments, "The world is a small place indeed." (p.123) After spending a long time in Berkeley, Narayan develops an attachment to the place and becomes attuned to its ambiance. He wonders, "I survive without a view of the Sather Gate Book Shop...I shall miss all those musical names of the streets...I shall miss all those scores of friends." (p.124) On his visit to Los Angeles, he was enchanted and enthralled by the city. He admires men and women. Mrs. Dorothy Jones arranges a tour for him to Hollywood. He met many people over there and was amazed to see the documentation of the work. He enjoyed cordial and cheerful conversation with the driver. There is also an interesting conversation about Narayan with the stranger, where the man spoke, "Your Country! A great job it's doing to keep the peace of the world. ....people don't want to live and let live, that's all...How Britain exploited India and other countries." (pp.130-1)

Narayan was delighted to see the idol of Shiva and Ganesha in the US. On his visit to Universal International Studios, he found that the people of film fraternity were disturbed by the attitude of the Indian government. They complained about how it is difficult to get permission for a movie project. Hollywood is full of yoga and philosophy. He saw Vedanta Plaza. In a selfrealization centre, he found that the first step for self-realization is good-food, then listening to lecture on vedanta. He saw many Americans attending lectures and living in an ashram. With Aldous Huxley, he went to see hills and a lake. He was amazed by Huxley's encyclopaedic mind. Huxley comments that in this country you find fantastic things side by side, "At one place you'll see huge advertisement for Forest Lawns, next to it whisky, health food and gambling at Las Vegas....you found things jumbled up, in this country." (p.142)

It seems Narayan is mesmerized by the beauty of the Grand Canyon which he has described in detail. He observes "its mighty quality... has to be felt...has versatility... a work of art 
by Nature...forms defy classification" and further adds, "all religions meet and merge...an unbearable agony, a mystic mood." (p.154) It leads him to compare with South Indian temples of Mahabalipuram and others such as their variegated architecture. He gives magnificent and picturesque descriptions of the canyon and it feels as if we were transported there. On his journey to Santa Fe through the desert of Arizona, he is amazed by the array of things coming across. From Lamy to La Fonda, he views a varied culture and cuisine. In the Museum of Folk Art, he found semblance with Indian artefacts. To him, "It must be co-ordinated work of Indian and American anthropologists" and the places give "appearance of Monkombu, Krishnarajapuram, Sivaganga and Seringapatam ...Santa Fe flavours...Indian background...Indian in deliberate costumes selling souvenirs." (p.157) At Bandelier National Monument there was an "amazing collection of relics of Pueblo Indians, who lived in ...eighth century ago" and it seems "a delicious moment of escape into a dim, pre-historic period." (158) He also visited St Miguel's Church, "the oldest church in the US." (p.161)

Narayan's visit to beautiful Sewanee, a place like Gurukula, is cheerful and happy. He likes its remote setting, free from distractions and allurement, an ideal place to "practise studies and discipline without any distraction." (p.163) However, on his journey to Washington D.C., he found in the bus depot "For Coloured" and "For White" being displayed. (p.164) Inside the bus the Whites were allowed to sit first, and even the driver manoeuvred the bus in such a way that they would board first. In Washington D.C., he sees "Government buildings, Government quarters, Government offices, and...officials of Indian embassy." (p.166) He visited several places such as Washington Memorial, Jefferson Memorial, and Lincoln Memorial and felt that they had the stamp of New Delhi and Bangalore. It seems Narayan could not resist the desire of comparing and contrasting the history and culture that energised him. He was impressed by the cleanliness and taxi service of the city. On St Patricks Day, there was a lot of festivity and fervour, a procession and drunkards.

His meeting with various people left him with the experience to have met "the finest types of human being," "rich and potent," "generous, ever-cheerful". (p.162-3) At Lexington, he met many of his Indian and American friends. When he met Greta Garbo, a Hollywood personality, he found himself enveloped by the questions related to our existence and life to which Narayan spoke about Karma, Gayatri Mantra, so on and so forth. During a concert of Ravi Shankar's sitar recital, when Narayan and other Indian were asked to sit down, other in the audience followed it. In recounting his experience, his readers enlists their own experience in it. Under his pen, America is assessed, resurrected, defined and created.

\section{Conclusion}

My Dateless Diary concludes with the words of Greta Garbo, "How I wish we could stop time from moving and always taking us on to a moment of parting!" (p.203) We also feel the same after reading the text. Through reading we "bring our experience, our active sense of life, to the different conceptions we encounter, working through them, comparing the alternatives they present, with, ...developing sense of what is important....we can live with, seeking a fit between experience and conception (Nussbaum, 1990, p. 25).

Travel imparts us insight, joy, experience, excitement, delight, knowledge, wisdom and discovery of our self. Travel indeed imparts new vigour to our life, it helps us in exploring and discovering our self, it also helps in self-realization and self-actualization. With further growth in the tourism industry, we hope that this genre of literature will grow further in the future. 
Narayan's experience reminds of "Little Gidding" by Eliot: "We shall not cease from exploration/ And the end of all our exploring / Will be to arrive where we started / And know the place for the first time." Before concluding it would not be out of place to quote from the end of Narayan's 1988 Foreword to the Penguin edition of the book:

But to return to the subject of this book. This is not a well-researched historical study of America and its inhabitants, merely a record of first impressions of people and places in that country. It should perhaps be read as a sort of subjective minor history of a country that I love. (n.p.)

\section{References}

Batten, Charles L. (1978). Pleasurable Instruction. Berkeley: University of California Press.

Fussell, P. (1982). Abroad: British Literary Travelling between the Wars. London: Oxford University Press.

Fixico, Donald L. (2000). The Urban Indian Experience in America. Albuquerque: University of New Mexico Press.

Eliot,T.S , "Little Gidding" Retrieved from www.poemhunter.com.

Korte, B. (200o). English Travel Writing from Pilgrimages to Postcolonial Explorations. Basingstoke: Macmillan.

Kumar, A. P. (2013) "R. K. Narayan as a Pragmatic Essayist", Language in India. 13 ( 10, October). 359-366. Retrieved from www.languageinindia.com

Narayan, R.K. (1960). My Dateless Diary: An American Journey. Mysore: Indian Thought Publications. Rpt. Delhi: Orient Paperbacks 1969; Penguin Books, 1988.

Nussbaum, M. C. (1990). Love’s Knowledge: Essays on Philosophy and Literature. New York: Oxford University Press.

Spengemann, W. C. (1977). The Adventurous Muse: The Poetics of American Fiction, 1780-190o. New Haven: Yale University Press.

Weinstein, F. (2001). Freud, Psychoanalysis, Social Theory: The Unfulfilled Promise. New York: State University Press New York.

Wells, J.C. (1982). Accents of English. Volume 3: Beyond the British Isles. New York: Cambridge University Press. 